\title{
BALDUINO RAMBO: A UNIDADE NA PLURALIDADE ${ }^{1}$
}

\author{
ARTHUR BLASIO RAMBO ${ }^{2}$
}

\section{RESUMO}

Mais do que eminente botânico e fitogeógrafo, Balduíno Rambo foi um dos mais importantes intelectuais brasileiros da primeira metade do século vinte, fato sobejamente comprovado em suas obras, reveladoras de apurada formação científica, literária, humanística, filosófica e teológica. O presente artigo visa, justamente, a destacar esta cosmovisão do autor, que o posiciona ao lado dos mais renomados pensadores de seu tempo.

\section{ABSTRACT}

[Balduino Rambo: the unity in plurality].

More than a distinguished botanist and phytogeographer, Balduino Rambo was one of the most important Brazilian intellectuals of the first half of the twentieth century, as abundantly demonstrated by the set of his work that shows accurate training, both in scientific sense, such as literary, humanistic, philosophical and theological. This article aims precisely to highlight the author's cosmovision, placing him alongside the most famous thinkers of his time.

Key words: Balduino Rambo, Rio Grande do Sul state.

\section{INTRODUÇÃO}

No mesmo ritmo em que avançam as investigações científicas e se aprofundam os conhecimentos sobre a natureza, esta parece sugerir cada vez mais uma realidade formada por elementos justapostos, sem uma aparente relação causal e/ou teleológica. A explicação, pelo menos em parte, deve ser procurada no método analítico que representa "o" instrumento de trabalho de todo pesquisador. Não há como conhecer as estruturas das matérias, entender os mecanismos que as fazem funcionar e as leis que comandam os processos naturais sem, por assim dizer, desconstruir a natureza até onde as ferramentas ao alcance dos cientistas são capazes de avançar. Há oitenta anos, Teilhard de Chardin escrevia que "a análise" vem a ser o

1 Recebido em 10-11-2011 e aceito para publicação em 05-1-2012.

2 Professor Titular emérito da UFRGS e da UNISINOS. Pesquisador do Memorial Jesuíta (UNISINOS, São Leopoldo - RS). Irmão de Balduíno Rambo. maravilhoso instrumento que abriu as portas de acesso a todos os conhecimentos de que dispomos atualmente sobre a natureza. $O$ filósofo, no entanto, não deixa de chamar atenção para o risco de que, de tanto desfazer sínteses, de tanto dissecar, de tanto analisar, se acaba perdendo a capacidade para enxergar o todo. E foi exatamente o aprofundamento e o aperfeiçoamento dos métodos e técnicas de análise, somados aos resultados em termos de conhecimento da natureza, que resultaram num distanciamento cada vez maior entre as Ciências Naturais e as Ciências do Espírito. Em não poucos casos, o afastamento levou os dois campos a se ignorarem, a se hostilizarem e a declararem-se guerra aberta. Não resta dúvida de que nessa guerra inglória só houve (e está havendo) perdedores.

Felizmente, pelo final do século XIX, quando ambos os arraiais se haviam encastelado em posições fundamentalistas irredutíveis, começaram a se vislumbrar sinais e acenos vindos de ambos os lados, apontando para uma reaproximação, e porque não reconciliação e ciolaboração. Especialistas vindos dos dois cam- 
pos e/ou transitando em ambos promoveram e protagonizaram o árduo caminho de retorno ao encontro da unidade do saber, de uma concepção holística do universo e da natureza. É verdade que a doutrina neoplatônica de que a "Verdade é o Todo", a convicção de Nicolau de Cusa de que o "Todo se'manifesta nas partes", e a teoria de Spinosa de que Deus é a substância infinita e causalidade imanente que mostra seus atributos infinitos em múltiplas modalidades finitas, nunca deixaram de contar com seus adeptos e defensores. Foi no clímax dos embates provocados entre os propagadores do monismo materialista de Ernest Haeckel e seus seguidores, e as posições não menos irredutíveis do lado do fundamentalismo religioso, ao final do século XIX, que entraram em cena cientistas defensores de uma visão unitária do mundo. Trata-se de pesquisadores em diversas especialidades e, ao mesmo tempo, portadores de uma apurada formação humanística, filosófica e teológica, entre os quais se salientam: o monge agostiniano Gregor Mendel, com justiça considerado o pai da genética; Hans Driesch, que formulou a teoria de que nos organismos vivos atua um "Princípio Vital"; Teilhard de Chardin, com sua grandiosa visão cósmica unitária; e Ludwig von Bertalanffy, que concebeu a natureza como um grande "Sistema" fundamentado sobre inúmeros "subsistemas" harmoniosamente estruturados e integrados. Entre a geração de cientistas vivos citam-se, ainda: Edward Wilson, entomólogo da Universidade de Harvard, que afirma ser a natureza "um fato objetivo"; e Francis Collins, diretor do "Projeto Genoma Humano", que chama a atenção de que a Natureza e o Universo formam uma unidade harmoniosa, apesar de todas as dissonâncias e cacofonias que atormentam o quotidiano das pessoas. A esses se somam os filiados ao "American Scientific Affiliation" e os que admitem, de alguma forma, a existência de Deus, e que totalizam $40 \%$ dos cientistas em atividade, no momento.
O Padre Balduino Rambo é um representante emblemático dessa geração de cientistas que, embora defendendo um viés próprio e original da visão integrada da natureza e da missão da pesquisa científica, se destaca, ainda, por sua posição declarada em favor da presença e do papel fundamental de Deus na natureza. Deus, para ele, é a razão de ser do Universo, da Natureza e do próprio Homem. A natureza, em outras palavras, na dimensão do macrocosmo, do microcosmo e do nanocosmo, revela, da forma mais convincente, a Sua existência.

\section{O PERFIL DE UM SÁBIO}

O centenário de nascimento do Padre Balduino Rambo motivou a publicação de um número considerável de matérias focando a vida e a obra desse ilustre jesuíta. Até hoje, quando seu nome é evocado, os que o conheceram ainda em vida ou entraram em contato com sua obra citam-no entre os homens de ciência mais destacados que honram o Rio Grande do Sul e o Brasil.

Sua obra mais conhecida e consultada é "A Fisionomia do Rio Grande do Sul", cuja primeira edição data de 1942. Baseia-se em dados e observações feitas em suas andanças pelo Estado, coletando exemplares de espécies da flora regional que formariam, na data de seu falecimento (1961), um gigantesco herbário de 90.000 exemplares. O estímulo propriamente dito para montar e escrever essa obra devem ser procurados, entretanto, nos sobrevoos que o Padre Rambo realizou para o Serviço Geográfico do Exército em começos de 1938 (Figura 1). Durante as 60 horas e 11.000 quilômetros percorridos, ele se deslumbrou com as paisagens mais variadas e surpreendentes que compõem o cenário natural ou, como ele diria, "A Fisionomia do Rio Grande do Sul".

Na parte do diário em que registrou essas vivências se pode perceber o quanto - e quão profundamente - as paisagens que deslizavam sob as asas do pequeno monomotor "Master 
Brasília", do Terceiro Regimento de Aviadores de Canoas, marcaram a sua relação "existencial" para com a querência natal. Ao amigo e colega de estudos na Alemanha, Waldemar Moll, assim resumiu essa experiência única para as circunstâncias de então: "Ah o prazer de voar! Acredito que voar vire paixão da qual não há como não cair vítima."

Foi a partir desses sobrevoos e da compreensão global que a contemplação do alto the proporcionava, que o Padre Rambo consolidou uma aproximação multifacética e multicromática da paisagem e da "História Natural" do Estado sulino. Em meio a esse cenário de reflexões foi tomando forma o projeto de sua obra clássica: "A Fisionomia do Rio Grande do Sul". Apreciada como um todo, ela vem a ser uma obra em forma de monografia, como ele próprio a classificou, bem ao estilo do velho (porém sempre novo e inesgotável) conceito de "História Natural".

A "Fisionomia do Rio Grande do Sul" conduz o leitor pelas diversas paisagens como se fosse um livro aberto. Na linguagem própria da sua natureza, a Mineralogia, a Petrografia, a Geologia, a Paleontologia, a Edafologia, a Hidrologia, a Botânica, a Zoologia e a Climatologia desenham as paisagens das diferentes regiões do Estado. Os conjuntos locais e/ ou regionais formam unidades que impressionam, assustam ou encantam. Cada qual, na sua identidade, vem a compor uma peça a mais na harmonia sinfônica da "Fisionomia do Rio Grande do Sul". Na medida em que detalhou com rigor científico a paisagem natural, apresentou-a ao público como uma declaração de amor apaixonada pela querência em que nasceu. $E$ a paisagem que mais fundo calou em sua alma de cientista e poeta foi o planalto coberto de pinheiros. No seu diário deixou o registro de que lá "à sombra das araucárias era sua pátria na terra".

O Padre Rambo vem a ser uma personalidade rara entre os sábios que transitaram com desenvoltura e competência pelos diversos campos do saber. Jovem, ainda, recém saído da ado- lescência, ele escreveu os primeiros versos e começou a redigir um diário. O gosto pela poética foi, por assim dizer, a sua paixão juvenil no campo das belas letras. O entusiasmo por esse gênero foi diminuindo até passar para um plano secundário quando chegou à plena maturidade, aos quarenta anos. $\mathrm{Na}$ ocasião, ele anotou em seu diário: "O gosto antigo pela poesia e a sensibilidade pela contemplação, é verdade não morreram em mim, mas recuaram para um espaço bem mais reduzido (...)". ${ }^{3} \mathrm{O}$ gosto pelos contos, isso sim, acompanhou-o até o falecimento em 1961, dos quais publicou 21 ao todo, e pelo gênero de correspondência, com mais de uma centena de cartas fictícias redigidas no dialeto Hunsrück. Essas cartas, como os contos, endereçavam-se aos descendentes dos imigrantes alemães no interior colonial. Trata-se de um conjunto de matérias que representam uma autêntica mina para estudiosos da língua e lingüística, da história, da antropologia, da sociologia, da religião e de outras especialidades. Além disso, encontram-se no espólio por ele deixado centenas de matérias sobre os temas em foco na sua época, que compreendeu o período da Segunda Guerra Mundial e os quinze primeiros anos do pós-guerra. De grande interesse para ele foram as mudanças de natureza cultural, social, econômica, política e religiosa, que mexeram fundo na vida e maneira de ser das comunidades do interior colonial, no qual ele próprio nascera e passara a infância. As raízes que deitara nesse meio tinham sido tão profundas e sólidas que, em vez de se enfraquecerem com o tempo, tornaram-se cada vez mais determinantes em sua produção literária. Lendo e examinando seus escritos, principalmente os de ficção, que foram inspirados na realidade humana do mundo rural, é lícito afirmar que eles teriam tudo para garantir-lhe um lugar de destaque na literatura mundial, caso tivesse se dedicado de corpo e alma ao gênero Conto, por exemplo.

\footnotetext{
3 RAMBO, B. Em busca da Grande Síntese. São Leopoldo: Editora Unisinos,1994. v. 1. p. 14.
} 
Um volume significativo de escritos do $\mathrm{Pa}$ dre Rambo, entretanto, é de natureza científica, com foco na Taxonomia Botânica. E foi a Botânica Sistemática que lhe valeu fama nacional e internacional. É óbvio que na descrição de um gênero, família ou espécie de Fanerógama não há espaço para divagações poéticas ou estéticas. $\mathrm{O}$ estilo dessa produção é enxuto, técnico, preciso e fático, como manda que sejam os textos com objetivos meramente científicos.

Entre os escritos essencialmente literários e puramente científicos, o legado do Padre Rambo contém um volume impressionante de outros textos, em sua maioria inéditos, e que ficam em patamar intermediário. Incluem-se, entre eles, a maior parte do diário pessoal, as descrições de excursões científicas, os relatos de viagens e o exemplo mais destacado e sua obra mais conhecida: "A Fisionomia do Rio Grande do Sul". Nesses textos não falta rigor científico. Os dados são reais, objetivos, mas os recursos literários e o estilo escolhido pelo autor vêm carregados de descrições que tocam os sentimentos, alimentam a fantasia e fazem com que o leitor viaje na imaginação, por uma paisagem viva, povoada de personagens, de dramas, de mistérios, de simbolismos, de significados, de misticismo. A forma de apresentar uma caminhada pelos campos de Cambará, por exemplo, não se resume a uma sucessão mecânica de atos para coletar o maior número possível de espécies de plantas. As reflexões que complementam a tarefa refletem a preocupação pelo lugar, de um todo mais amplo, e os simbolismos de que os mínimos detalhes são portadores. Ao mesmo tempo, seus escritos sugerem e fazem vislumbrar, em meio à infinita multiplicidade de detalhes, a convergência harmônica numa unidade que confere sentido a tudo. Renato Dalto, autor do texto da obra comemorativa ao centenário do nascimento de Rambo, resumiu, com rara precisão, o que vínhamos tentando dizer:

O Padre Balduino Rambo nasceu, viveu, pesquisou e se expressou na natureza. Quan- do menino, ainda no pátio da casa paterna, em Tupandi, região de colonização alemã no vale do Caí, onde nasceu no ano de 1905, considerava as árvores no fundo da casa seu brinquedo predileto. Quando foi estudar na Escola Apostólica, em Pareci Novo, em 1917, o passeio pelas matas dos arredores lhe aguçou o gosto pela Botânica e a Geografia. Isto foi determinante na sua vida de pesquisador. Seus relatos da natureza são grandes mapas descritivos - o conceito de fisionomia, no qual primeiramente enxerga o todo para depois entrar nos detalhes. $\mathrm{O}$ detalhe é visão do botânico, mas há também a busca da síntese entre ciência e religião, os questionamentos da alma, o vigor literário e a construção poética de ver couraça revestindo pedras, atribuir memória a acidentes geológicos, escutar a canção das águas, ouvir o murmúrio do divino em meio à névoa da noite. ${ }^{4}$

Foi e é ainda exatamente essa forma peculiar de apresentar dados isolados, paisagens locais ou fisionomias naturais globais, que fizeram do Padre Rambo um sábio de reconhecimento perene. Seus ex-alunos da Universidade Federal do Rio Grande do Sul e do Colégio Anchieta, ainda vivos, bem como intelectuais que privaram com ele ou vieram a conhecê-lo pela obra que deixou, lembram de Rambo com sincera veneração. Guardam dele a memória de um especialista e sábio que soube aliar, como poucos, o rigor científico à sensibilidade de um poeta, a reflexões filosóficas e, jesuíta que era, a enxergar na paisagem natural as marcas e a presença do Criador. Sobre este ponto, Renato Dalto resume, com rara felicidade: "Talvez visse nos pinheirais a mediação entre o céu e a terra, um caminho próximo para entender a Deus". 5

Tomando em conta os múltiplos campos de conhecimento em que o Padre Rambo se movimentou, entende-se que sua obra encontre difi-

${ }^{4}$ DALTO, R. Aparados da Serra: na trilha do Padre Rambo. São leopoldo: Editora Unisinos, 2007. p. 12.

DALTO, R., 2007. Op. cit., p. 12. 
culdades para ser avaliada, seja no todo ou nos diversos enfoques. Começando pelos diversos campos aos quais ele se dedicou e deixou reflexões escritas, fica difícil (senão impossível) decidir em que campo específico ele foi maior. E como "maior" não entendemos aqui o volume da produção específica, senão o significado e o valor de cada uma. Uma avaliação do conjunto da produção literária não deixa dúvidas sobre o valor tanto do objeto quanto da forma com que é apresentado. A leitura dos contos e das cartas fictícias era disputada com avidez e paixão pelo público leitor a quem foi endereçado. Outra série de contos em alemão erudito, versando sobre temas regionais do sul do Brasil, atingiu um público leitor internacional, pois foram publicados na revista alemã "Katholische Missionen” (Missões Católicas), de circulação internacional. Entre os títulos mais citados destacam-se: o conto "Der Held vom Berge Taiô" (O herói do monte Taiô), versando sobre a batalha de sobrevivência dos índios em Santa Catarina; "Langeneckers Sägemühle" (A Serraria dos Langenäcker), que aborda o começo da colonização no oeste de Santa Catarina; e "Leben um Leben" (Vida por Vida - traduzido e publicado em português), que tem como pano de fundo a revolta dos "fanáticos" em Santa Catarina. O manuscrito de outro conto de notável conteúdo somente foi localizado após o falecimento do autor, e publicado na versão original (em alemão) pelo Padre Arthur Rabuske, de saudosa memória: "Drei Jahre auf dem Mars" (Três Anos em Marte). Permito-me reproduzir aqui, com mais ou menos fidelidade, o que escrevi sobre esse conto no livro comemorativo "A Pluralidade na Unidade - Memória, Religião, Cultura e Ciência”.

O conto constitui-se numa critica bem humorada e sutil, embora ácida e impiedosa, ao valor exagerado que se costuma emprestar a tudo que é "moderno" (ou "pós-moderno", diríamos hoje), e os reflexos sobre a civilização nele fundamentada. Escrito por volta de 1958, esse conto consiste numa antevisão do potencial da tecnologia e seus efeitos projetados para o futuro. Suas páginas deixam nítida impressão de termos, em mãos, reflexões e prognósticos de um profeta que anteviu, no atacado e no varejo, cơno as conquistas da ciência e tecnologia moldariam o perfil da civilização à entrada do terceiro milênio. Bạlduíno Rambo valeu-se do conto para alcançar o objetivo de alertar - não os colonos do interior, mas o universo culto sobre os exageros e as consequiências do mau uso das tecnologias que se vinham multiplicando e sofisticando. Esse gênero literário pareceulhe o de maior potencial didático para transmitir as suas idéias, alertas e ensinamentos. Desse mesmo recurso ele já se valera para escrever outro conto, intitulado "Três semanas na Lua", em que alertava sobre os riscos e inconvenientes das colonizações no norte do Mato Grosso, começadas em meados da década de 1950 pela Transportadora Meyer, de Porto Alegre.

O cenário do conto é o planeta Marte, por isso "Três Anos em Marte". As histórias de discos voadores, de viajantes vindos do espaço cósmico (Marte, de preferência) e a viagem espacial do astronauta russo Gagarin povoavam, na época, a imaginação até das pessoas mais simples. Valendo-se desse imaginário, o autor montou o pano de fundo literário para transmitir a sua antevisão do que seria a civilização do futuro, completamente dominada e subordinada aos recursos criados pela tecnologia. A história começa numa dessas noites de verão, típicas de Cambará, São Francisco de Paula, São José dos Ausentes, Jaquirana ou Bom Jesus. O Padre Rambo alimentava verdadeira paixão por aqueles campos e precipícios cobertos de pastagens naturais, capões e florestas onde imperava a Araucária e, nas caídas para o oceano, a Mata Atlântica. Durante as férias de verão ele se deslocava para aquele cenário praticamente intacto. Passava dias e semanas perambulando por aquela paisagem única, coletando plantas e entregue às suas reflexões prediletas. Pois, segundo ele próprio conta, em certa noite de fevereiro, meados de 1950 , ele foi surpreendido 
pelo pouso de um disco voador procedente de Marte. Os marcianos que o tripulavam levavam um convite para dar preleções sobre Biologia e Filosofia Natural na Universidade Central de Marte, a "Alma Mater Martiana". Não lhe foi dado muito tempo para se decidir. O convite soava quase como um aviso de seqüestro. Pergunta-se qual a razão dos marcianos terem buscado no Planeta Terra um professor para lecionar aqueles conteúdos. A resposta veio clara e inequívoca, logo ao pousarem em Marte. Toda a população concentrava-se numa gigantesca metrópole. Nela tudo era artificial e sintético, desde os materiais de construção, passando pelos alimentos, vestimentas, meios de comunicação, lazer e transporte - tudo, enfim. O povo consumia os dias na mais absoluta artificialidade. Tinha perdido a noção dos valores mais elevados e elementares, como sociabilidade, solidariedade e compromisso mútuo, sem falar nos valores éticos, morais e religiosos.

A maior parte da superfície de Marte voltara a ser sepultada pela natureza selvagem primitiva. Sem necessidade de desenvolver a agricultura, nem a criação de animais e recursos naturais de qualquer tipo, florestas imensas ocupavam os dois hemisférios do planeta. Em alguns vales remotos ainda se podiam encontrar raros sobreviventes dos habitantes primitivos, em estado próximo à barbárie. Os laboratórios que aperfeiçoavam, sofisticavam e acirravam sem parar essa civilização, distanciando-se sempre mais dos conhecimentos ligados ao espírito, concentravam-se num único complexo de pesquisa: a "Alma Mater Martiana”, a Universidade Central de Marte. Nela dominava uma atividade frenética, em constante aceleração, para dar conta das novas tecnologias, superadas a cada dia. Em meio a essa efervescência e da repercussão de seus resultados, uma incômoda preocupação foi tomando conta dos responsáveis pela universidade e das pessoas comuns em geral. A dúvida que questionava a aposta irrestrita na técnica, desacompanhada de um mínimo de conhecimentos mais gerais, levava a civilização de Marte a um beco sem saída. Uma pergunta incômoda atormentava os marcianos. E uma vez esgotadas todas as potencialidades embutidas na ciência e tecnologia, por onde sair? Apostaram, então, nos "ultrapassados" e "inúteis" conhecimentos gerais para recolocar a ciência e tecnologia nos seus devidos lugares, mostrar suas limitações e alertar sobre a finitude do seu potencial. Para começar, era preciso recolocar a Ciência e Tecnologia no seu devido lugar hierárquico e chamar de volta as Ciências do Espírito, para alertar de que é indispensável uma compreensão global dos fenômenos da natureza e, ao mesmo tempo, estimular a reflexão sobre a razão de ser da vida e do universo. Acontece que profissionais do pensamento e do conhecimento desse nível ou, porque não, autênticos sábios, já não podiam ser encontrados em Marte. Os marcianos foram buscá-los no distante e estranho Planeta Terra. ${ }^{6}$

Além de ser uma peça literária primorosa, o conto "Três Anos em Marte" põe em evidência o pólo para o qual convergiam todos os interesses do Padre Rambo. Os textos que ele deixou, além do que acabamos de mencionar, muitos deles ainda inéditos, bem como os diários de suas viagens internacionais (em 1956, para os Estados Unidos, e em 1959 para a Alemanha, como convidado oficial do governo daqueles países), demonstram o que lhe interessava de fato: descobrir, na diversidade das manifestações, o fio condutor que as une e lhes dá sentido. E se há uma baliza, uma referência que confere harmonia ao aparente caos, qual a sua natureza? Na condição de jesuíta, ele estava comprometido com a crença de que tudo o que existe na natureza visível tem origem e razão de ser num Deus Criador. Deixou essa posição explícita num dialogo com o Criador, registrado no seu diário a 24 de junho de 1945 :

\footnotetext{
6 RAMBO, A.B. Novas respostas para velhas perguntas. In: RAMBO, A.B.; GRÜTZMANN, I.; ARENDT, I.C. Pe. Balduino Rambo. A pluralidade na unidade. São Leopoldo: Ed. Unisinos, 2007. p. 22-23.
} 
À primeira vista, a Tua Criação nem mesmo se apresenta como ordenada, mas como uma grande confusão: grande confusão o teu firmamento estrelado, grande confusão os edifícios dos reinos do saber, uma confusão muitas vezes horripilante o roteiro da Tua Providência na História da Humanidade. Nós, cientistas, trazemos dentro de nós um certo pressentimento e um salutar temor face a toda esta confusão. Imprimiste em nós um resplendor do Teu próprio ser e por isso sabemos, de antemão, que por trás dessa aparente balbúrdia reina uma maravilhosa harmonia. Mais, ainda! Que é tarefa nossa perseguir as meadas deste sistema e explicar com transparência sua interligação. Até certo ponto somos nisso bem sucedidos e às vezes invade-nos a ilusão de termos descoberto a planta do mundo e agora a saberíamos fixar no papel preto sobre branco. Pena que, num último momento, alguma das tuas divagações ou digressões põe sempre em dúvida a consistência de todo esse edifício! Eis porque somos obrigados a sempre recomeçar, embora saibamos perfeitamente que também esta vez a conta não irá fechar. Empilham-se nossos livros, e nossas bibliotecas continuam a crescer que é uma barbaridade. Muitos dos nossos opinam que a partir das raízes desse tronco frágil podem esquadrinhar o próprio mistério da Tua ordem universal. Desenrolam e vasculham os pergaminhos de épocas passadas, dialogam com traças e escorpiões de livros, reduzem cinqüenta velhos volumes a um só, e chamam tal proeza de "Ciência"?

Um exame um pouco mais minucioso dessa reflexão põe em evidência, entre outras, as duas facetas de seu autor. A primeira é a do cientista, especialista em Botânica Sistemática, que percorreu sem descanso, durante décadas, os cenários naturais do Rio Grande do Sul, coletando plantas. Em seu recinto de estudo, Rambo acondicionou estas plantas, ordenou-as e as classificou segundo os rígidos preceitos da Taxonomia.

7 RAMBO, B. Em busca da Grande Síntese. São Leopoldo: Editora Unisinos, 1994. v. 1. p. 127-128.
$\mathrm{O}$ resultado final veio a constituir-se na maior coleção de fanerógamos do País, somando cerca de 90.000 exemplares. Foi esse afã de sistemata e as dezenas de artigos rigorosamente científicos que lhe abriram as portas para o livre trânsito na comunidade científica internacional. Basta uma olhada na sua correspondência científica para desfazer qualquer dúvida a respeito. Curiosamente, entretanto, este trabalho e seus resultados, que seriam orgulho de qualquer cientista, para o Padre Rambo não passaram de um caminho penoso, de um pressuposto desgastante em busca dos dados objetivos, para com eles, em mãos, partir para identificar o significado no todo da natureza e do universo. Deixou claro, no Diário, o quanto esse trabalho ingrato, embora necessário para o seu objetivo maior, lhe pesava sobre os ombros:
À medida que me entretenho com a descrição das Ciências Naturais, experimento em mim mesmo uma espécie de esvaziamento da vida afetiva. Apodera-se de mim a sensação de que o ser cadavérico das plantas mortas reflete-se em minha alma, como se minha vida interior assimilasse, mais e mais, $o$ aspecto inanima- do do meu cemitério de plantas. A ocupação constante com as descrições latinas apenas esquemáticas, geralmente áridas e inanima- das, projetam sua cor mortiça sobre a alma, tornando-a embotada, gélida e apática. ${ }^{8}$

Pode-se afirmar que, em termos gerais, a obra do Padre Rambo sempre gozou da admiração e do reconhecimento nacional e internacional, tanto pelo rigor científico quanto pela forma como é oferecida ao público. Atestam-no a abundante correspondência com os grandes centros de pesquisa em Botânica Sistemática da época. Provam-no, também, as viagens de três meses cada uma, como convidado oficial do governo americano (em 1956) e da Alemanha (1959). Ambas tiveram como objetivo proporcionar, ao

\footnotetext{
8 RAMBO, B., 1994. Op. cit., p. 13.
} 
cientista, visitas de estudo a centros e institutos de pesquisa, a universidades, museus, parques, reservas florestais, etc. Especialmente importantes foram as visitas aos grandes parques nacionais dos Estados Unidos. Inspiraram páginas de reflexão sobre o que observava, de uma rara beleza literária e profundidade espiritual, registradas no diário de quase quatrocentas páginas, escrito durante aquela viagem. Tudo o interessou, a começar, é claro, pela vegetação, passando pela formação geológica, pela saga histórica dos indígenas e a conquista da região pelo colonizador branco, os rituais que regiam o quotidiano dos visitantes nos parques e a própria razão de ser desses cenários, que permitem lazer sadio até às pessoas mais simples. Já na "Fisionomia do Rio Grande do Sul" ele deixara clara a preocupação pela preservação do meio ambiente mediante ações concretas, factíveis entre nós, no sul do Brasil. Na ocasião, ele deixou a advertência de que

O homem, o filho desta terra, que lhe fornece o pão de cada dia e os símbolos e sua vida espiritual, sente um respeito inato perante a fisionomia desta sua mãe e pátria. Enquanto o espaço é suficiente e a densidade demográfica pequena, não se tornam muito conscientes tais sentimentos; mas no momento em que as necessidades brutais da vida forçam a interferir sempre mais na expressão natural do ambiente, desperta a dor perante a destruição de suas feições naturais, e o desejo de as conservar, senão no conjunto, ao menos em alguns lugares e nos traços mais característi$\cos$. Assim, no curso de todas as culturas humanas, mais cedo ou mais tarde, surgem as tendências de proteção ativa da natureza; um povo que se descuidasse deste elemento, seria falto dum requisito essencial da verdadeira cultura humana total, e indigno da terra com que a pródiga mão do Criador o presenteou. ${ }^{9}$

9 RAMBO, B. A fisionomia do Rio Grande do Sul. Ensaio de monografia natural. Porto Alegre: Of. Gráf. da Imprensa Oficial, 1942. p. 337-338.
O projeto efetivo, porém, para a implantação de um parque no Rio Grande do Sul amadureceu naquelas visitas aos parques nacionais americanos:

Desde que voltei da América, empenhei-me para que aqui no Brasil se implantassem mais parques nacionais. Até agora dispomos somente de dois, um nas terras montanhosas do Itatiaia e o outro nas cataratas do Iguaçu. Se tudo correr bem, teremos, em breve, um terceiro nas escarpas orientais dos Aparados da Serra, com o Itaimbezinho como núcleo inicial. O lamentável é que entre nós constróise, em primeiro lugar, um enorme hotel para atrair os turistas endinheirados de dentro e fora do País. Com isso está viciado o conceito de um autêntico parque. O parque deve estar a serviço da proteção da natureza e do recreio do povo. O rico que aparecer, deve ser obrigado a viver com a mesma simplicidade que o operário e o colono. As pessoas que não conseguem dispensar o hotel caro, o rádio, televisão, a dança e o jogo, que fiquem onde tudo isso está disponível de qualquer forma. Em nenhum parque jamais escutei um rádio berrando, nem observei um aparelho de televisão, nem percebi música e dança. De maneira alguma quero afirmar que o americano médio é melhor do que nós. Uma coisa, porém, é certa. Eles têm mais compreensão, mais decência e mais respeito perante a beleza e tranqüilidade da natureza criada por Deus. ${ }^{10}$

A combinação do rigor científico com uma forma literária vigorosa e reflexões de natureza histórica, antropológica, sociológica, filosófica, teológica e até mística, faz um número relativamente pequeno de intelectuais desclassificarem ou diminuírem o Padre Rambo como autoridade científica. Como acontece em tais situações, alguns opinam por ouvir falar, outros leram e não entenderam; outros, ainda, acham que cientista só é aquele que apresenta

\footnotetext{
${ }^{10}$ RAMBO, B. A nacionalização. Arquivo do Padre Rambo (inédito), 1958. p. 222.
} 
dados objetivos, frios, verificáveis, quantificáveis, fotografáveis ou aferíveis por meios empíricos. Refletir sobre esses dados objetivos, buscar sentidos, simbolismos, construir a partir deles uma cosmovisão, encontrar convergências, causas e teleologias, depõe contra a cientificidade do autor. Classificam sua produção como alienada, coisa de romântico sonhador e afirmações do gênero. Pior quando parte de um preconceito puro e simples contra a pessoa, como parece ser, em alguns casos, em relação ao Padre Rambo. Resumindo: dizem que o homem não merece a fama de cientista de que goza. Felizmente, os que assim pensam constituem insignificante minoria e sua opinião não chega a arranhar o respeito conquistado por ele com sua obra. Aliás, ele não foi uma exceção entre homens que marcaram época com seus trabalhos de pesquisa científica e, a partir dela, formularam compreensões mais abrangentes da natureza, do homem e do universo e continuam sendo respeitados e citados até hoje. Sua fama, entretanto, não se explica tanto pela revolução nas descobertas formalmente consideradas científicas, quanto pela cosmovisão elaborada a partir delas. Entre esses cientistas, que podemos classificar de verdadeiros sábios, se encontram, por exemplo, o padre jesuíta Erich Wassmann, seu irmão de ordem Teilhard de Chardin, o biólogo Ludwig von Bertalanffy, o diretor do Projeto Genoma, Francis Collins, e Edward Wilson, um entomologista de Harvard.

\section{A CONCEPÇÃO HOLÍSTICA}

$\mathrm{O}$ inestimável mérito dos cientistas anteriormente citados, e de um número crescente de outros, vindos de todas as áreas das Ciências Naturais, consiste no esforço de construir pontes entre estas e as Ciências do Espírito.

Nos Estados Unidos, eles fundaram a "American Scientific Affiliation", uma associação que reúne cientistas que admitem a idéia de que forças extra-naturais atuam na Natureza. Depois de dois séculos de distanciamento entre as Ciências Naturais e as Ciências do Espírito; depois de inúmeros embates entre os dois arraiais, visando o enfraquecimento e, se possível, a derrota e a anulação do adversário; depois de décadas de guerra declarada, na qual só houve perdedores, começou um movimento discreto, no sentido contrário.

Ao final do século XIX, o monge agostiniano austríaco Gregor Mendel realizou pesquisas pioneiras no campo da hereditariedade, formulando as leis fundamentais da herança biológica. Trata-se de uma dessas descobertas dotadas de um potencial de pesquisa pura e de aplicação prática que seu autor jamais teria imaginado. Se hoje, cento e trinta anos passados, a Biogenética ocupa um lugar de primeira ordem entre as especialidades da Biologia, tanto para a pesquisa pura quanto para a aplicada, o mérito cabe a Gregor Mendel e suas ervilhas, na horta do convento de Brün, na Áustria.

Contemporâneo de Mendel, o padre diocesano Girolamo Bresadolla tornou-se um dos mais conceituados micólogos da época. Foi o mestre e incentivador do padre jesuíta Johannes Rick, que conquistou fama internacional com seus estudos sobre fungos, realizados no sul do Brasil entre 1904 e 1945. Nenhum dos três nomes acima citados se empenhou, explicitamente, em mostrar o quanto as Ciências Naturais, as Ciências do Espírito e as Humanas têm a lucrar quando promovem o intercâmbio mútuo de resultados, quando, em vez de competir, colaboram entre si.

Quem apresentou, de fato, um caminho válido para superar o impasse criado pelo distanciamento (para não dizer ruptura) entre os grandes campos do conhecimento foi também outro religioso e jesuíta, em parte contemporâneo de Mendel, Bresadolla e Rick. Referimo-nos a Erich Wassmann, natural de Merano (Meran), no Tirol do Sul. Ainda hoje, quando citado, ele é lembrado como o "homem das formigas", uma vez que passou a vida inteira pesquisando sociedades de formigas e 
térmites. Interessava-lhe, de modo especial, a relação simbiótica entre formigas e térmites com determinadas espécies de fungos, base da sobrevivência e prosperidade nas colônias desses insetos. Além de numerosos artigos descritivos dos processos que comandam a vida dessas colônias, ele se dedicou a especulações que ultrapassam preocupações taxonômicas ou de etologia animal. Suas reflexões concentraramse sobre as fronteiras entre a Ciência e a Filosofia. Em resumo, perguntava-se "qual o papel que cabe à Ciência e qual o papel que cabe à Filosofia" numa aproximação compreensiva da natureza como um todo e de suas partes em particular. Como ferramenta de trabalho e referenciais explicativos, valeu-se de dois conceitos: "Weltbild" e "Weltauffassung". O responsável pelo desenho do "Weltbild - Retrato do Mundo" vem a ser a Ciência e os cientistas. $\mathrm{O}$ responsável pela "Weltauffassung - Compreensão do Mundo, Cosmovisão" é tarefa do filósofo. Explicou que o "Weltbild" resulta da observação das realidades naturais em si, das relações mútuas e das leis que as regem, assim como são formuladas nas hipóteses e teorias científicas. Resulta daí o quadro da natureza que fixa a situação momentânea em que encontram os conhecimentos. "Weltbild", portanto, corresponde à imagem do universo, do mundo e da natureza, assim como a Ciência o retrata a cada momento. O cientista, valendo-se das leis da física, da química, da estatística, da matemática, etc., procura entender os acontecimentos de seu interesse, bem como formular hipóteses e teorias para compreender a natureza. Em outras palavras, para desenhar a imagem concreta e palpável da natureza: o "Weltbild".

O segundo conceito com que Wassmann trabalhou foi "Weltauffassung - Concepção do Mundo". Neste nível pergunta-se pela causa primeira, pelo sentido ontológico da natureza como um todo, o plural no todo, a teleologia. Em última análise, pergunta-se pelo "porque", pelo sentido que rege a dinâmica dos acontecimentos. Resumindo, afirma-se que o "Weltbild" é a representação real, tangível, palpável, mensurável, visível, que a Ciência desenha com os dados empíricos que seus métodos e técnicas oferecem. "Weltauffassung" é a concepção do mundo, a cosmovisão, o resultado dos esforços da Filosofia. Com isso fica claro que o pesquisador ou cientista não tem como ultrapassar o nível dos dados objetivos sem o recurso a categorias filosóficas. "Cada teoria envolvendo a natureza contém um elemento metafísico, na medida em que procura identificar as relações entre as realidades apreensíveis experimentalmente", diz Wassmann. De outra parte, o filósofo movimenta-se no campo da metafísica em busca do extra-sensível. Cabe a ele responder a interrogações mais substantivas, mais fundamentais, sobre a origem das leis naturais e a harmonia que reina entre elas. ${ }^{11}$

Desde que Wassmann publicou as reflexões acima já se passaram mais de noventa anos, mas, em essência, o foco da questão em nada se modificou. Neste meio tempo, as Ciências Naturais fizeram avanços gigantescos. A física desvendou o micro-mundo da estrutura da matéria até os seus últimos componentes e identificou as leis que regem o átomo e seu funcionamento. Criou tecnologias com as quais seus potenciais energéticos podem ser controlados e utilizados como poderosas fontes de energia, tanto para fins pacíficos quanto bélicos. Tendo como fundamento remoto as descobertas das leis fundamentais da genética, por Mendel, uma imersão não menos profunda aconteceu na trama e na própria mecânica dos processos da vida. A partir daí, os cientistas desenvolveram tecnologias que permitiram desvendar os segredos da estrutura e funcionamento do genoma humano e de uma lista considerável de outros seres vivos. E de posse desses conhecimentos desenvolveramse tecnologias que permitem canalizar os potenciais dos mesmos para as mais diversas finalidades. A manipulação genética de plantas e

\footnotetext{
${ }^{11}$ WASSMANN, E. Stimmen der Zeit, 1921, v. 100, p.
} 126-127. 
animais (e do próprio homem) está aberta e em pleno andamento, acompanhada pelos riscos, benefícios e, também, por desvios e aberrações. Técnicas de manipulação são de uso corrente no tratamento de males hereditários e/ou de prédisposição hereditária, que afetam a saúde do homem e interferem na qualidade de plantas e animais.

E o que realmente trouxeram de novo essas conquistas do último século? Em termos de concepção da natureza, de "cosmovisão", de "Weltauffassung", a rigor nada de fundamentalmente novo. Aqueles cientistas que apostam todas as fichas na convicção de que o progresso, o avanço e o aperfeiçoamento dos métodos de investigação terminarão desvendando e explicando as últimas incógnitas que envolvem a natureza e a própria vida, não passam de herdeiros, no século XX e XXI, da concepção mecanicista monista de Ernest Haeckel, Huxley, Morgan e outros do século XIX.

Um outro segmento de cientistas e, de modo especial, de pesquisadores na linha interdisciplinar formulou as mesmas perguntas, colocando as mesmas objeções dos seus colegas de cem anos passados: qual a identidade das causas que geraram as primeiras realidades materiais, as energias, os processos e a matéria prima de que é formado o universo; qual a causalidade suficiente que gerou as primeiras formas de vida e as potencializou para se transformarem e evoluírem para a infinidade de formas e estágios que povoaram (e ainda povoam) a terra, inclusive o homem? Também nesse plano as respostas mais ou menos cautelosas, mais ou menos ousadas, não sofreram alterações substantivas. Todos concordam em afirmar, ou pelo menos sugerir, que os processos, as leis, as estruturas e a matéria prima que compõem o universo não são causa suficiente para produzir efeitos como a vida, a sensibilidade, a inteligência reflexa do homem, assim como a própria existência da matéria ou a energia que lhe deu origem.
As respostas a essas questões variam na forma e na insistência, de acordo com a época e a filiação filosófica, teológica e confessional do autor. Erich Wassmann resumiu a sua posição nos seguintes termos:

Aqui se oculta uma linha de pensamento eminentemente teleológica. Se for levada às últimas conseqüências lógicas, termina necessariamente no reconhecimento de um Criador pessoal, responsável pelas leis da natureza, pois as leis da evolução devem ter sido concebidas pelo mesmo legislador que outorgou as leis da evolução dos seres vivos. Esse legislador só pode ser uma sabedoria supramundana, que, como causa prima, regula e engloba a natureza toda e suas leis. Assim, as adaptações orgânicas constituem-se num testemunho vivo, numa prova da moderna concepção teísta do mundo. ${ }^{12}$

Erich Wassmann, cientista que foi, convenceu-se de que suas sociedades e colônias de formigas e térmites faziam parte de processos de transformação que operam na evolução como motores do acontecer da história da vida. $\mathrm{O}$ parasitismo e a simbiose, que faz parte da própria natureza dessas sociedades de insetos, só pode ter-se consolidado ao longo de processos muito demorados. Padre jesuíta que foi, comprometido com a ortodoxia, cabia-lhe a obrigação de encontrar uma saída calcada em bases sólidas, tanto na Ciência quanto na Filosofia e Teologia. E pelo que se pode avaliar deu um passo significativo nessa direção. Para ele, tanto as evidências do transformismo, quanto o princípio filosófico da causalidade e o conseqüente pressuposto doutrinário da atuação de um Criador na Natureza, eram dados inegociáveis.

Como não podia deixar de acontecer, de um lado autoridades eclesiásticas conservadoras se

12 WASSMANN, E. Stimmen der Zeit, v. 100, 1921, p. 136. 
empenharam em bloquear os avanços das idéias evolucionistas. Por outro lado, muitos cientistas extrapolaram e avançaram para além de seu campo específico e, valendo-se dos resultados de suas investigações, utilizaram-nas para municiar suas investidas contra a Igreja, a religião ou qualquer outra concepção não afinada com o ideário monista materialista.

Na mesma direção de Erich Wassmann, mas avançando mais no aprofundamento da compreensão do homem e do universo, situa-se seu irmão de ordem, Pierre Teilhard de Chardin. Ambos, cientistas e pesquisadores de renome internacional, partiram dos resultados de suas investigações para formular respostas a questões de fundo, que envolvem a origem, a gênese e a evolução da matéria, da vida e do próprio homem. Wassmann encontrou os dados empíricos nas observações do parasitismo e da relação simbiótica entre fungos e bactérias, em ninhos de formigas e térmites. Teilhard de Chardin valeu-se dos conhecimentos de química, física e biologia, somados a observações paleoantropológicas, etnográficas e etnológicas, realizadas na China, na Europa e na América.

No prefácio que escreveu para o livro de Teilhard, "O Homem na Natureza", Jean Piveteau, da Academia Francesa de Ciências de Paris, resumiu a compreensão do autor sobre o mundo e a natureza:

A vida está longe de ser uma combinação fortuita de elementos materiais, um acidente da história do mundo, mas a forma que a matéria assume num certo nível de complexidade. Ela introduz-nos numa ordem nova, caracterizada por propriedades peculiares, a biosfera. Ela não deve ser concebida como uma imagem puramente espacial, um mero invólucro concêntrico da litosfera, uma espécie de quadro onde a vida é confirmada, mas como uma camada estrutural do nosso planeta, "um dispositivo no qual transparece a ligação que une entre si, no seio de um mesmo dinamismo cósmico, Biologia, Física, Astronomia". A vida manifesta muito rapidamente uma das suas tendências mais fundamentais, a tendência de se ramificar enquanto avança. ${ }^{13}$

E o próprio Teilhard chama a atenção:

(...) mas o seu grande interesse em ascender a uma posição privilegiada a partir da qual descobrimos com emoção, que se o homem deixou de ser (como antes se pensaria) o centro imóvel de um mundo acabado, em contrapartida, ele tende doravante a representar, para a nossa experiência, a ponta de lança de um universo em vias, simultaneamente, de "complexificação" material e de "interiorização psíquica sempre mais acelerada. Uma visão cujo choque sobre o nosso espírito deveria ser suficientemente forte para exaltar ou mesmo para transformar a nossa filosofia. ${ }^{14}$

Ambos, tanto Teilhard de Chardin quanto Erich Wassmann, contaram em seus currículos com uma excelente formação científica, humanística, filosófica e teológica. Preocupados com os questionamentos formulados pelo avanço das investigações científicas às posições tradicionais relativas à compreensão do universo, da natureza e do homem, foram buscar respostas nos próprios dados científicos. Wassmann as encontrou nos ninhos de formigas e térmites, Teilhard em todos os campos das Ciências Naturais e Humanas. Demonstrando familiaridade com a Física, Química, Biologia, Antropologia, Etnografia, Etnologia, Etnohistória, Filosofia e Teologia, Teilhard concebeu e formulou sua grandiosa e ousada cosmovisão da gênese e evolução da matéria, da vida e do homem.

Nas suas reflexões sobre a natureza da matéria, dos processos químicos e das leis da física, Teilhard visa, em última análise, a definir o "lugar do homem na natureza". A compreensão do homem constitui-se, para Teilhard, na chave da compreensão da natureza como um todo. Sem

${ }^{13}$ CHARDIN, T. de. O lugar do Homem na Natureza. Lisboa: Instituto Piaget, 1956. p. 9-10.

${ }^{14}$ CHARDIN, T. de, 1956. Op. cit., p. 15-16. 
compreender o homem, o universo e a natureza são incompreensíveis e, por isso mesmo, não fazem sentido. $\mathrm{O}$ universo não faz sentido sem a presença nele do homem na sua totalidade existencial, na sua dimensão físico-corporal, racional e espiritual. Mais: ao longo de sua obra Teilhard vai insinuando que, assim como o universo e a natureza não fazem sentido sem a presença do homem, o homem não faz sentido e também o universo (e a natureza) não faz sentido, se o todo não é impulsionado por uma dinâmica teleológica que comanda e orienta o acontecer na natureza. E, a partir dessa constatação, a lógica do raciocínio leva a concluir que na origem dessa dinâmica atuou uma causa; de que essa causa conferiu ordem aos processos e os orientou para um objetivo final. Ou não seria esse o sentido do "alfa" como ponto de partida e do "ômega" como destino final? Ou, ainda, a metáfora do globo terrestre de que se valeu. $\mathrm{O}$ pólo sul simboliza o começo, o ponto de partida, o "alfa"; e o pólo norte o ponto de chegada, o destino final, o "ômega". Entre os dois pólos aconteceu e continua acontecendo a gênese e a história do universo, da natureza e do homem. A primeira fase, que tem o seu lugar no hemisfério sul, corresponde a uma diversificação, uma complexificação e uma expansão em direção ao equador. Na segunda fase, no hemisfério norte, a diversificação vai diminuindo e a complexificação cedendo lugar a uma tendência de "compressão" crescente, simulando um afunilamento, na medida em que se aproxima do pólo norte, ou do "ômega". O que acontece com o universo como um todo, repete-se individualmente em cada espécie viva, inclusive no homem.

Para entender o homem e atribuir-lhe o lugar que lhe cabe no universo, a natureza percorreu um longo caminho. Esse caminho foi marcado por um começo, um ponto de partida que prima pela simplicidade perceptível na ausência de diversidade e impulsionada por processos químicos e princípios físicos elementares. No começo havia apenas energia. Da concen- tração da energia resultou a matéria primordial. Tudo o que aconteceu, então, durante bilhões de anos, resume-se na concentração e na complexificaçãō da matéria original. Teilhard assim se expressou: "A vida, repetirei ao longo de todas as páginas, apresenta-se experimentalmente à Ciência como um efeito da complexificação". ${ }^{15}$ E para que esse conceito-chave não induza em equívoco, continua definindo claramente de que tipo de concentração está falando. Negativamente, complexificação não é sinônimo de agregação, como acontece com uma pilha de tijolos ou a repetição geométrica que rege o "crescimento" de um cristal.
(...) a combinação, ou seja, essa forma parti- cular e superior de agrupamento cuja missão é ligar a si mesmo um certo número fixo de elementos (poucos ou muitos, não importa), com ou sem contributo auxiliar de agregação e de repetição, num conjunto fechado, com raio determinado: o átomo, a molécula, a cé- lula, o metazoário. ${ }^{16}$

Sempre segundo Teilhard, estamos, aqui, diante dos componentes e dos processos dos quais resultou a infinita complexidade do mundo, palco do homem e da sua história. Abstraindo da complexificação por agregação e da complexificação por repetição, fiquemos apenas com a complexificação por combinação. Nesse processo, a agregação e repetição entram apenas como mecanismos complementares e secundários. Nos dois casos o elemento "inacabado" é da essência do processo. À pilha de tijolos podem-se acrescentar tantas unidades quantas quisermos, sem modificar a sua natureza. Um cristal admite a incorporação na sua rede estrutural de um número indefinido de átomos, moléculas e ramificações. Faz parte da natureza dessas duas modalidades de estruturação estar sempre aberta a novos acréscimos, tanto na

${ }^{15}$ CHARDIN, T. de, 1956. Op. cit., p. 27.

${ }^{16}$ CHARDIN, T. de, 1956. Op. cit., p. 28. 
estrutura, quanto no número de elementos que a compõem.

Com a complexificação por combinação, colocada como base do seu pensamento por Teilhard, as coisas passam-se de outra maneira. A “combinação" resulta, em cada etapa, numa estrutura acabada em si mesma; porém, a partir de um certo momento começa a dar sinais de um potencial interno de desdobramento ilimitado. Dessa forma um "corpúsculo", tratandose tanto de uma unidade micro, macro ou mega, embora limitado em seu contorno estrutural, a partir de um determinado nível de complexidade começa a manifestar sinais efetivos de "autonomia". Com o auxílio desses conceitos, Teilhard atribui a evolução, a transformação, a complexificação, o avanço autônomo da natureza, ou qualquer outro termo que se prefira, a um tal ou qual "centro complexidade".

Ludwig von Bertalanffy (1901-1972) foi mais um desses representantes emblemáticos que empenharam o melhor dos esforços no sentido de encontrar na natureza algo mais do que elementos justapostos, leis físicas e processos biológicos, atuando fortuitamente e sem relações em nível de causa e efeito. Nasceu na época em que as leis da hereditariedade de Mendel foram redescobertas, por assim dizer, e fizeram sua entrada triunfal na galeria dos avanços mais revolucionários da Biologia. A sua iniciação nas Ciências Naturais, nas Letras, nas Artes e na Filosofia, como adolescente na Universidade de Innsbruck, coincidiu com os famosos debates travados entre Ernest Haeckel e os admiradores do monismo materialista, Hans Driesch e, principalmente, Erich Wassmann, defensores de uma compreensão holística da natureza. Ludwig von Betalanffy consolidou sua proposta "organísmico-sistêmica" do universo e da natureza na mesma época (1920 - 1950) em que Teilhard de Chardin formulou sua grandiosa concepção da evolução natural, e Balduino Rambo deixou registrado, em seu diário, dados e elementos para uma não menos ousada síntese entre as Ciências Naturais e as Ciências do Espírito. Mas as coincidências não se limitam ao período cronológico em que os nomes acima consolidaram suas concepções. Assemelham-se, também, pelos conhecimentos que faziam parte da sua formação humanística aliada a uma sólida formação científica.

Em resumo: Bertalanffy conquistou um nome respeitado entre pensadores e cientistas porque sinalizou, tanto para o filósofo quanto para o teólogo e os homens da ciência, um caminho possível para superar as dificuldades do diálogo instalado entre essas diversas áreas do conhecimento. Na evolução do pensamento de von Bertalanffy observam-se dois momentos, o primeiro dos quais localiza-se em fins de 1940 e começos de 1950. Em 1949 saiu, pela Editora Franke, o "Biologisches Weltbild" e, em 1951, pela mesma editora, a "Theoretische Biologie". No primeiro, um volume relativamente modesto (cerca de 120 páginas), o autor expôs a sua "concepção organísmica" dos seres vivos. $\mathrm{Na}$ "Theoretische Biologie", ele apresentou os dados empíricos que fornecem a base científica para a "Teoria Organísmica". O segundo momento do amadurecimento e de consolidação definitiva da visão da natureza de von Bertalanffy verificou-se na década de 1960 e culmina com a publicação da obra "General Theory of Systems", em 1968, traduzida para o português e editada pela Vozes, sob o titulo de "Teoria Geral dos Sistemas".

Entre a publicação do "Biologisches Weltbild" e "General Theory of Systems" passaram-se 17 anos. Como incansável pensador e cientista, von Bertalanffy foi ampliando e aprofundando as bases empíricas sobre as quais (e a partir das quais) terminaria formulando a "Teoria Geral dos Sistemas", obra que resume, por assim dizer, a caminhada científica e filosófica do autor, falecido em 1972 . O fio condutor, o "Leitmotiv" do esforço de três décadas de rigorosas investigações científicas, acompanhadas por reflexões de não menor profundidade, resultou numa obra que não pode passar despercebida para aqueles que lidam com questões 
de fronteira entre as Ciências Naturais e as Ciências do Espírito. O ponto de partida parece ter sido uma aproximação da questão mais pelo lado filosófico do que pelo científico, pois, uma conferência de von Bertalanffy, publicada em Viena, em 1947, leva o titulo: "Vom Sinn und der Einheit der Wissenschaften" (O Sentido e a unidade das Ciências Naturais). Dois anos mais tarde veio à luz o "Biologisches Weltbild" (O Retrato biológico do Mundo). Apoiado em observações, caracteriza o organismo vivo como um "sistema aberto", o que impede que seja visto como simples soma das estruturas e funções que o integram.

Estamos, portanto, diante de um cientistafilósofo que busca na Matemática, na Física, na Química e nos diversos campos da Biologia, elementos e argumentos capazes de dar suporte e solidez à sua proposta "organísmico-sistêmica" . Percebe-se, nesse particular, um parentesco não declarado entre o paradigma conceitual e o caminho para implementá-lo de Erich Wassmann, quando atribui às Ciências Naturais o papel de desenhar o "Weltbild", o retrato, a situação, o estado da arte sugerido pelos dados científicos disponíveis no momento. Von Bertalanffy valese do mesmo conceito, com o mesmo sentido, no "Biologisches Weltbild" e o faz permear as páginas da "Teoria Geral dos Sistemas". Não se vale do conceito de "Weltauffassung", com o destaque que lhe empresta Wassmann, mas, no último parágrafo da sua obra, conclui com uma afirmação inequívoca nesse sentido:

A concepção mecanicista do mundo dominante no século passado relacionava-se estreitamente com o predomínio da máquina, a concepção teórica dos seres vivos como máquinas e a mecanização do próprio homem. Os conceitos cunhados pelos modernos progressos científicos têm, porém, sua mais evidente explicação na própria vida. Assim há esperança de que o novo conceito do mundo estabelecido pela ciência seja a expressão de um progresso dirigido para um novo estágio da cultura humana. ${ }^{17}$

Ludwig von Bertalanffy pretende, por meio da sua Teoria Geral dos Sistemas, encontrar uma saída para superar o impasse frente à fragmentação em todos os sentidos e em todos os níveis, engendrada pela civilização pós-moderna. Tanto as Ciências Naturais quanto as Ciências do Espírito, valendo-se de métodos analíticos a serviço de uma visão mecanicista, de tanto dissecar, perderam a noção da vida que animou a célula, o genoma, o DNA, que observam com o microscópio. O químico, o físico, o geneticista, o geógrafo, o economista, o antropólogo, o historiador, o sociólogo, o filósofo e até o teólogo recolhem-se aos seus casulos impermeáveis. A perda da capacidade de perceber o Todo, a Totalidade, é diretamente proporcional ao avanço das suas descobertas e elucubrações. No final, só restam tecidos, peças de máquina, fatos e idéias dispersas. Há mais de 70 anos, Teilhard de Chardin, prenunciando a pós-modernidade que se avizinhava, chamou a atenção:

Ao contrário dos primitivos que dão personalidade a tudo que se mexe, ou mesmo dos primeiros grupos que divinizavam todos os aspectos, todas as forças da natureza, o homem moderno tem a obsessão de despersonalizar ou impersonalizar o que mais admira. Duas razões para essa tendência. A primeira, é a análise - esse maravilhoso instrumento da pesquisa científica, ao qual devemos todos os nossos progressos - mas que, de síntese em síntese desfeita, deixa escapar, uma após outra, todas as almas e acaba por nos deixar perante uma pilha de engrenagens desmontadas e de partículas que se esvaem. E a segunda, é a descoberta do mundo sideral, objeto tão vasto que se tem a impressão de que toda a pro-

\footnotetext{
${ }^{17}$ BERTALANFFY, L. von. Teoria geral dos sistemas.
} Petrópolis: Vozes, 2008. p. 333. 
porção entre o nosso ser e as dimensões do Cosmos à nossa volta, foi abolida. ${ }^{18}$

A questão de fundo a ser resolvida como passo inicial para refazer a "síntese desfeita" é devolver-lhe a alma. Consiste, em última análise, na reeducação da mente de como se percebe o universo, o mundo e tudo que o que nele se encontra. A análise como filosofia de ação e método científico teve o grande mérito de levar até à compreensão das bases estruturais e funcionais da natureza e da própria vida. A estrutura atômica já não é mais segredo e a mecânica do seu funcionamento encontra aplicação pacífica de um lado e, do outro, funciona como poderoso instrumento de intimidação e de chantagem. Com a compreensão da estrutura e natureza do genoma, incluindo o humano, tem-se como entender a base material da vida, as leis que comandam o seu funcionamento e, consequentemente, está aberto o caminho para enfrentar males e moléstias com base hereditária, melhorar geneticamente plantas e animais e, o que seria uma aberração, manipular seres humanos com finalidade eugênica. Frente a esse quadro do avanço da ciência e tecnologia não é difícil concluir que, de tanto lidar com tijolos, perde-se a noção da casa em si; de tanto preocupar-se com as árvores, perde-se a noção de floresta; de tanto dissecar tecidos, não se percebe mais o organismo; de tanto desmontar células, vai-se a perspectiva de que foram vivas e desempenharam o papel de fundamentos estruturais e funcionais da vida. Estendendo essa linha de raciocínio a outros campos, chega-se sempre à mesma conclusão. Conceitos como "Totalidade", "Unidade", não contam na avaliação dos dados, dos benefícios ou dos malefícios que resultam das descobertas feitas no campo científico. O mesmo fenômeno, ressalvadas as peculiaridades, pode ser aplicado aos campos de conhecimento relacionados diretamente com

${ }^{18}$ CHARDIN, T. de. O fenômeno humano. São Paulo: Ed. Cultrix, 1986. p. 293. o homem: Sociologia, História, Direito, Economia, Letras e Literatura, Filosofia, Teologia. Em alguns mais, outros menos, a visão mecanicista e os correspondentes métodos analíticos de trabalho levaram a um aprofundamento de valor inegável. Aos que apostam todas as fichas na incursão cada vez mais acelerada e mais refinada em direção às perguntas ainda sem resposta, passa despercebido que há um contraponto a essa realidade que não pode ser ignorado. A noção da "Totalidade" e da "Unidade" diminui na mesma proporção em que se avança e se aprofunda o conhecimento especializado. $\mathrm{O}$ resultado que mais preocupa resume-se num endemismo do espírito, em que o particular, o detalhe, as leis formuladas a partir de métodos de natureza diferente, próprios a objetos também diversos, são usados para emitir juízos de valor sobre fatos e realidades também diferentes. Quando se chega a esse ponto, a situação se complica. O cientista extrapola dos resultados obtidos em seu laboratório e sai dando palpites sobre questões de ética e moral, e a questionar princípios doutrinários privativos do teólogo. Vindos da outra ponta, filósofos e teólogos intrometem-se em assuntos que competem ao cientista e seus métodos e instrumentos. O cenário que resulta da mútua invasão indevida de territórios e competências termina, não raro, numa guerra inglória, inútil e prejudicial, em que só há perdedores, com prejuízos incalculáveis tanto para as Ciências Naturais quanto para as Ciências do Espírito.

O remédio proposto por Ludwig von Bertalanffy a fim de superar esse impasse, consiste numa mudança profunda de natureza teórica e, consequentemente, de natureza metodológica. Em vez de partir do pressuposto de que se chega à compreensão do todo desmontando-o até os últimos componentes, é preciso partir de uma outra perspectiva. A peça deve ser entendida a partir da máquina, da célula, do tecido, do órgão, do aparelho a partir do organismo como um sistema. A natureza de um ser vivo não se descobre desmontando as células 
que o compõem em seus elementos estruturais e funcionais, mas buscando entender a sua razão de ser, suas funções a partir do todo, a partir da funcionalidade que lhe é própria enquanto no todo ou, como diria Bertalanffy, enquanto atua no "Sistema". E, assim, estamos diante do conceito-chave que Ludwig von Bertalanffy criou. A natureza como um todo (e suas partes) forma um "Sistema" e o mega-sistema global é formado por inúmeros subsistemas estrutural e funcionalmente integrados e complementares, com aplicação para todos os níveis de complexificação em que a natureza possa ser escalonada.

As considerações até aqui apresentadas permitem concluir que os diversos níveis de organização da natureza se integram horizontal e verticalmente um com os outros, como fatores de equilíbrio. Dessa forma, a natureza concebida como um todo forma um "Sistema", cuja integridade, saúde, perenidade e vigor dependem da presença e qualidade dos seus componentes e da relação e interdependência harmoniosa entre as partes. $\mathrm{O}$ mundo, ambiente em que o homem vive e sobrevive, não passa de um gigantesco e complexo "Sistema Global", construído sobre estruturas frágeis que interagem numa dinâmica de relações mútuas não menos vulneráveis e, por isso mesmo, facilmente sujeitos a danos irreversíveis. Qualquer intervenção, positiva ou negativa, por mais insignificante que possa parecer, se reflete de alguma forma no todo. Não resta dúvida de que a percepção sistêmica, assim como von Bertalanffy a concebeu, pressupõe que a natureza forme um todo, uma totalidade. Os esforços para salvar a vida do planeta só fazem sentido se vistos nessa perspectiva.

A boa nova consiste no fato de que esse ponto de vista vem sendo defendido, não apenas por filósofos na linha de Platão, Santo Agostinho, Nicolau de Cusa, Spinosa e outros, mas por um número crescente de cientistas de renome, partindo dos resultados das pesquisas especializadas de cada um. $\mathrm{O}$ espaço disponível não permite multiplicar a análise de outros especialistas que defenderam uma visão globalizante da natureza. Apenas como mais uma amostra permitimo-nos apresentar o resumo da compreensão de Edward Wilson, que há mais de 50 anos se dedica à Entomologia na Universidade de Harvard. Na sua mais recente obra - "The Criation - an appel to save life on Earth" -, traduzido para o português com o titulo de "A Criação - um apelo para salvar a vida na Terra”, depois de analisar os resultados de pesquisas realizadas nos ecossistemas das ilhas que compõem o Parque Nacional "Boston Harbor Islands" e as ilhas "Florida Keys", no Golfo do México, e florestas tropicais fortemente humanizadas com pastagens, fez a seguinte reflexão:

\begin{abstract}
Alguns filósofos pós-modernos, convencidos de que a verdade é relativa e dependente apenas da visão do mundo de cada um, argumentam que não existe uma entidade objetiva tal como a "Natureza". Para eles trata-se de uma falsa dicotomia, que surgiu em algumas culturas e não em outras. Estou disposto a levar em conta esse ponto de vista, ao menos por alguns minutos, mas já atravessei tantas fronteiras nítidas entre ecossistemas naturais e humanizados que não posso duvidar da existência objetiva da "Natureza". ${ }^{19}$
\end{abstract}

A conclusão a que chegou Edward Wilson, um pesquisador reconhecido mundialmente, merece séria reflexão. Nela o autor toca em questões de fundo, que deveriam ficar muito claras e presentes, e servirem de orientação quando o assunto é meio-ambiente, políticas ambientais, economia sustentável, políticas e ações de preservação e termos do gênero. "A existência da Natureza é um fato objetivo". E fatos objetivos requerem abordagens científicas e filosóficas objetivas. Os desafios que essa verdade elemen-

${ }^{19}$ WILSON, E., 2008. A criação - Um apelo para salvar a vida na Terra. São Paulo: Companhia das Letras, 2008. p. 31. 
tar coloca para qualquer pessoa séria, tanto para os representantes das Ciências Naturais quanto das Ciências do Espírito, são enormes e assustam. Entender as causas que atuam na natureza, as leis e mecanismos que determinam seu funcionamento, enxergar o seu destino em termos gerais e do homem em particular, não é tarefa para amadores ou simples ativistas. Exige espíritos desarmados, conhecimentos especializados, instituições aparelhadas, centros de estudo e reflexão de alto nível. Não há lugar e vez para abordagens simplistas à base de receitas ditadas por convicções pré-concebidas, nem do lado das Ciências Naturais, nem do lado das Ciências do Espírito. Questões como "Natureza", "Meio Ambiente", "Origem das Espécies", "Consciência", "Memória", "Instinto", "Inteligência", "Reflexão", não admitem serem tratados num ambiente de beligerância inútil e fundamentalismo estéril. Exigem, como ponto de partida, mentes preparadas e, principalmente, espíritos desarmados. Por sorte, nomes com esse perfil estão se tornando cada vez mais freqüentes. É interessante destacar mais uma peculiaridade de Edward Wilson: o que faz dele um exemplo emblemático é o fato de ele ter defendido uma postura firme contra os fundamentalistas de algumas denominações religiosas em relação à Bíblia, assim como os fundamentalistas do lado das Ciências Naturais que rejeitam qualquer outra abordagem ou interpretação que não seja a "científica". Na sua obra publicada em 2006, em português, com o titulo de "A Criação - um apelo para salvar a vida na terra", Edward Wilson propõe um pacto de colaboração entre a Ciência e a Religião, na forma de uma carta a um pastor evangélico.

Meus alicerces referenciais foram a cultura da ciência e algo do secularismo na ciência, tal como eu o compreendo. A partir dessa base, concentrei-me na interação de três problemas da educação científica e as confusões morais causadas pelo crescimento exponencial da Biologia. Para solucionar esses problemas, como já argumentei, será necessário encon- trar um terreno comum onde as poderosas forças da Religião e da Ciência se possam unir. E o melhor lugar é começar a tarefa zelando pela vida.

Tanto o senhor como eu somos humanistas no sentido mais amplo. $\mathrm{O}$ bem-estar da humanidade está no centro dos nossos pensamentos. Mas a diferença entre o humanismo baseado na Ciência irradia-se por toda a filosofia, e até pelo sentido que atribuímos a nós mesmos como espécie. Essa diferença afeta a maneira como cada um de nós valida a nossa ética, nosso patriotismo, nossa estrutura social, nossa dignidade pessoal.

O que devemos fazer? Esquecer as diferenças, digo eu. Encontramo-nos no terreno comum. Isto talvez não seja tão fácil como parece à primeira vista. Pensando bem, nossas diferenças metafísicas tem um efeito notavelmente pequeno sobre a conduta da sua vida e da minha. Minha suposição é de que ambos somos pessoas éticas, patrióticas e altruístas, mais ou menos no mesmo grau. Somos produto de uma civilização que surgiu não só da religião como, igualmente, do iluminismo fundamentado na ciência. De boa vontade nós dois serviríamos no mesmo júri, lutaríamos nas mesmas guerras e tentaríamos, com a mesma intensidade, santificar a vida humana. E, com certeza, compartilhamos o amor pela Criação. ${ }^{20}$

Os exemplos que acabamos de registrar representam apenas uma amostra de representantes de livre trânsito no universo científico, que formularam propostas no sentido de uma concepção unitária (holística) do universo e da natureza. Para Nicolau de Cusa, o "todo se expressa nas partes"; para Spinoza, Deus é a única e infinita substância que, como causalidade imanente, manifesta os seus atributos infinitos em múltiplas modalidades finitas; para a “cosmovisão - Weltauffassung” de Erich Wassmann; a dinâmica da gênese e evolução de Teilhard de Chardin que tem o seu ponto de partida no "alfa" e termina no "ômega" como

${ }^{20}$ WILSON, E., 2008. Op. cit., p. 188. 
síntese final; para Ludwig von Bertalanffy que percebe a natureza e suas partes formando sistemas; para Edward Wilson a natureza é uma "realidade objetiva"; para Francis Collins a natureza apresenta-se, a quem tem sensibilidade de ouvir, como uma grande sinfonia executada por milhões de instrumentos perfeitamente afinados.

\section{A COSMOVISÃO DE RAMBO}

Dos cientistas citados, cada qual expressou, à sua maneira, a convicção de que a Natureza forma, em última análise, uma unidade estrutural, funcional e teleológica. Tentemos agora identificar quais as impressões, os sentimentos e a compreensão que povoaram o íntimo do Padre Rambo nas suas andanças pela natureza. Mais acima destaquei que a porção mais volumosa dos escritos, dos seus escritos, a grande maioria encontráveis no seu diário, se apresentam na forma de reflexões literariamente ricas, rigorosamente científicas e filosoficamente densas. Foi ele próprio que resumiu o que é a ciência e como e porque merece ser praticada:

A ciência apenas possui então valor para cultivar o que o cientista tem de humano (Menschlichkeit) - (para a formação humana do cientista) quando empreendida e praticada a partir do todo e estruturada dentro do todo. Pressupõe isso um treinamento escolar geral voltado para o todo - coisa que foge à grande maioria dos pesquisadores atuais. (...) A ciência quando praticada com acerto é uma recriação espiritual do mundo, uma atividade semelhante à de Deus, dando assim em culto divino. $^{21}$

Salvo melhor juízo, está aí, em síntese por ele mesmo formulada, a essência, a razão de ser da dedicação à ciência, a maneira de conduzi-la e a sua destinação maior. E essa destinação maior consiste em humanizar o pesquisador e o

\footnotetext{
${ }^{21}$ RAMBO, B. Diário do retiro (inédito), 31 de julho a $1^{\circ}$ de agosto de 1949.
}

cientista, e este, por sua vez, irradiar o seu "humanum" para o mundo em seu derredor. Pressupõe-se para tanto que o pesquisador desenvolva sua tarefa inspirado numa cosmovisão unitária, holística e integradora da natureza. E é nesse particular que reside o "nó górdio" que é preciso desatar. A questão não se resolve cortando-o com a espada, como fez o general romano, mas desatando-o. Requer-se para tanto, da parte do pesquisador, do cientista, uma formação acadêmica de visão ampla e abrangente, capaz de partir de uma noção do todo em que se move. É preciso que saiba comunicar-se com estilo, maestria e paixão, tanto nos seus escritos quanto nos seus discursos. Vai na linha da proposta pedagógica conhecida como "oxbridge", na Inglaterra, que tem como objetivo formar um "gentleman", um cidadão completo, não um especialista bitolado, munido de viseiras. Os antigos romanos falavam em "vir bonus, peritus dicendi" - "Um homem bom, que sabe comunicar-se". Esses conceitos pouco ou nada têm a ver com o sentido quase depreciativo como são conhecidos popularmente. A palavra "gentleman" pressupõe uma pessoa educada, correta, ética, culta, dotada de sensibilidade artística. "Peritus dicendi", por sua vez, é o cidadão que tem algo de útil a comunicar e o sabe fazer com elegância. Não é vulgar, ignorante, grosseiro, mas conhecedor e sabedor do que fala. Salvo melhor juízo, o pensamento do Padre Rambo vai nessa direção ao definir o verdadeiro fazer Ciência:

Ciência verdadeira começa apenas ali onde ela se tornou culto pessoal a Deus para o próprio pesquisador. E isso muito antes de qualquer idéia relativa à publicidade. Ciência vem a ser um decifrar dos vestígios de Deus e um respeitoso reescrever imitativo do Mundo, portanto, um estudo artístico de primeira ordem e grandeza. Ciência é uma contemplação contínua e a cópia desejada dos planos arquitetônicos secretos e misteriosos do Mundo. E uma vez que tudo isso equivale à reconstrução imitativa e ao entender por dentro 
das coisas de sua ordem hierárquica - tudo no espelho de uma personalidade marcante em extremo - a Ciência é uma arte verdadeira. Próprio, contudo, de toda a obra de arte é que irradie da plenitude e ordem hierárquica de cada uma de suas partes, de sua ancoragem no belo todo do Cosmos e de seu parentesco com o Arquétipo, que se encontra além de toda a beleza artística, despedindo de si um calor e um reflexo de luz, aos quais não pode subtrair-se nenhum homem de pensamento hierárquico. Apenas dali, portanto, a partir da plenitude de uma riqueza interior, começa a atividade exteriorizada da Ciência, pois, sendo verdadeira, ela é um facho aceso e reluzente, similar aos sóis do firmamento, que avançam espalhando benefícios por sua mera existência. ${ }^{22}$

Nessa passagem do Diário Pessoal o Padre Rambo condensou a sua compreensão do universo e da natureza como um todo e em suas partes. Definiu a razão última de ser da Ciência como sendo o "culto a Deus". Por isso, a tarefa do autêntico cientista resume-se em reescrever, redesenhar, cantar em prosa e verso essa grandiosa obra em homenagem ao Supremo Artista. O que importa, em última análise, como resultado final da atividade científica, consiste em descobrir em a natureza "os planos arquitetônicos secretos e misteriosos do Mundo”. E, identificando a arquitetura singular dos componentes da natureza, descobrir as relações estruturais, funcionais e hierárquicas que os inserem num todo maior, numa unidade superior, num "sistema global", como diria Ludwig von Bertalanffy. Com esse pano de fundo Renato Dalto foi de uma rara felicidade ao resumir as características da obra científica do Padre Rambo.

Seus relatos da natureza são grandes mapas descritivos - o conceito fisionomia, no qual primeiramente enxerga o todo para depois entrar nos detalhes. O detalhe é a visão do

${ }^{22}$ RAMBO, B. Diário (inédito), 3 de junho de 1951. botânico, mas há também a busca da síntese entre a ciência e a religião, os questionamentos da alma, o vigor literário e a construção poética capaz de ver couraça revestindo pedras, atribuir memória a acidentes geológicos, escutar a canção das águas, ouvir o murmúrio do chamado divino em meio à névoa da noite. ${ }^{23}$

Para ilustrar a rara capacidade desenhar os "mapas descritivos", de dar rosto e forma às "fisionomias" que foi observando, recorri ao diário que o Padre Rambo redigiu por ocasião da sua visita aos parques nacionais do oeste americano, a convite do governo daquele país. Ao entrar no Parque de Yosemite, flagrou-se diante de um cenário de sonho. Depois de fazer reflexões sobre o significado histórico, econômico, humano e antropológico da grande corrida ao ouro na Califórnia nos anos cinqüenta do século XIX, no vale do rio Merced, cujas nascentes se encontram no parque, deu vazão às emoções diante de um panorama empolgante:

Acontece que não viajei para a Sierra Nevada à procura de ouro, mas em busca do mais belo vale do mundo, o vale de Yosemite. As montanhas aproximam-se cada vez mais umas das outras. O rio troveja com crescente força sobre os escombros de rochas, a floresta permite a visão livre e eu contemplo um cenário de fadas, como não existe outro igual. $\mathrm{O}$ Merced, aqui reduzido a um arroio largo, rumoreja aos meus pés. As águas são tão cristalinas que permitem contar as pedras no fundo e observar a dança das trutas. Mais para o fundo abre-se um prado coberto de capim verde, de canas com pontas reluzindo como ouro, e no meio delas, milhares de flores brancas, vermelhas, amarelas e azuis. Mais adiante ergue-se a floresta formada por árvores majestosas: pinheiros, cedros e pinheiros Douglas. À direita precipita-se a cascata Véu de Noiva, do alto de um vale de mil metros e desfaz-se em espuma. Também à direita sobe a mil metros de altura um bloco de granito

\footnotetext{
${ }^{23}$ DALTO, R., 2007. Op. cit., p. 12.
} 
tingido de vermelho pelo sol da tarde. Deram-lhe o nome de "el Capitán". É o rochedo sentinela no portal de entrada do vale das maravilhas. E bem no fundo do vale outro cume de rochedo sobressai às montanhas, o "Half Dome", o mais famoso da Sierra Nevada. E estendendo-se sobre o panorama todo o céu azul, e sobre ele navegam suavemente os brancos veleiros de Deus. ${ }^{24}$

Depois de desenhado o mapa panorâmico do vale de Yosemite numa forma literária em que sobressai o tom épico, o Padre Rambo faz a descrição científica dos componentes do vale. Em primeiro lugar, explica a gênese geológica e a moldagem final da paisagem durante o último período glacial. Detalha depois a fauna do parque e, de modo especial, a composição da flora que, como botânico, lhe chamava especial atenção. Chama a atenção a um dos maiores inimigos da floresta do parque, causado por um fungo que se serve de um arbusto hospedeiro para depois atacar as árvores. Informa também que o volume de neve acumulada no vale permite predizer a disponibilidade de água para irrigar os pomares e vinhedos do vale da Califórnia. E depois, acomodado no alto de um dos rochedos que formam o vale, volta a desenhar um "mapa" do parque visto do alto e de um outro ângulo:

Pouco antes do meio dia chegamos ao "Glacier Point", um rochedo na extremidade superior do vale de Yosemite. Com certeza devem existir poucos lugares na terra, de onde se descortinam paisagens tão deslumbrantes. Para a direita a vista alonga-se por sobre as serras intocadas até os cumes cobertos de neve das montanhas mais altas. Do lago Merced nasce o rio do mesmo nome, precipitando-se em duas cascatas: o Nevada Fall de 160 metros e o Vernal Fall com 95. Em frente, no lado oposto do vale, ergue-se o maior bloco de granito do mundo, o Half Dome com 2.760 metros acima do nível do mar e 1.500 metros

${ }^{24}$ RAMBO, B. Três meses na América. Manuscrito (inédito), 1956. p. 148-149. a prumo sobre o chão do vale. Para a esquerda desfruta-se uma visão sobre todo o vale, $\mathrm{e}$ mais adiante, sobre os altiplanos dos dois lados, inúmeros milhares de pinheiros Jeffrey, isolados, em grupos, formando florestas fechadas, parecem um exército de soldados, aprestando-se para o assalto aos cumes das montanhas. Onde quer que haja uma saliência, uma fenda, um lugar para um pé, agarram-se os arbustos, carvalhos anões, castanheiras anãs, azaléias anãs. Essas últimas vestem na primavera os gigantes de pedra das montanhas com um manto real de púrpura nas suas cores mais esplendorosas. Aos meus pés, o paredão de rochas precipita-se perpendicularmente por 976 metros. As fitas de um azul negro das estradas com os carros multicoloridos circulando nelas; a faixa azul clara do rio entre a floresta escura e os prados cor de ouro; as cidades de barracas e cabanas ao longo do rio, na floresta, ao pé da grande cascata; as multiformes rochas na beirada; o Half Dome fendido ao meio, os Arcos Reais, o Pináculo das Águias, a Torre de Observação, as Torres da Catedral; o Capitão Sentinela - tudo compõe um quadro que somente um foi capaz de conceber: Aquele que no canto de Habacuc, marcha sobre as montanhas e as faz estremecer sob o passo marcial de suas eternidades. ${ }^{25}$

Mais acima já apontamos que o Padre Rambo nasceu em 1905, numa propriedade rural de pequenos agricultores, no vale do rio Caí. $\mathrm{Na}$ época ainda havia poucos moradores na parte superior da bacia daquele rio. A casa em que ele nasceu, toda construída em madeira, desde os fundamentos até a cobertura do telhado, ficava a poucos metros da mata virgem que cobria ainda mais da metade da propriedade. $\mathrm{O}$ fato de ter sido o primeiro filho do casal Nicolau e Gertrudes, acrescido ao fato do irmão seguinte ter nascido só quatro anos depois, fez de Balduino um menino solitário, tendo como companhia e como brinquedo dos primeiros anos de infância, a floresta virgem com suas árvores,

${ }^{25}$ RAMBO, B. 1956. Op. cit., p. 151. 
seus pássaros e seus animais silvestres. Ele mesmo deixou escrito no diário que seu brinquedo predileto foram as árvores da floresta. Com isso interiorizou uma relação profunda, indelével e existencial com ela. Foi para ele uma fonte de reflexões, de simbolismos, de vivências como nenhuma outra realidade natural. Uma caminhada solitária por alguma floresta despertava-lhe os sentimentos mais variados, as emoções mais profundas, os simbolismos e metáforas mais surpreendentes. Parece que um poderoso vulcão irrompia do seu fundo existencial enquanto perambulava por uma floresta. Em seu diário da visita a Yosemite ele próprio descreveu um desses momentos, ao caminhar pela floresta de sequóias gigantes do parque:

Em meio à floresta sem igual há um pequeno museu no qual o professor universitário Frank Potter e sua esposa explicam aos hóspedes tudo que merece ser conhecido. Onde as sequóias se concentram em grande número, como em volta desse museu, difunde-se por toda a parte na floresta o brilho marrom vermelho da sua casca. Centenas de árvores novas que se confundem com ciprestes ladeiam os caminhos. Misturadas com as sequóias e formando a massa principal da floresta, crescem milhares de cedros da Califórnia, pinheiros brancos, pinheiros Douglas, que em altura não perdem para os gigantes, embora raras vezes passem de dois metros de diâmetro. Um líquen amarelo-ouro reveste o tronco do pinheiro branco. O reflexo mescla-se com o marrom claro da casca da sequóia e, combinado com as manchas do sol e a sombra, resultam numa luz colorida de extrema suavidade, envolvendo todo o chão da floresta. Sem querer a gente se descobre e se sente pequenino como um camundongo entre esses gigantes reunidos em conselho. Que cantos não teriam deixado os poetas cantores do Antigo Testamento, que falam com tanta empolgação dos cedros do Líbano e dos gigantes do Monte Sião, se tivessem escutado a voz de Deus nessas florestas. Enquanto Davi e Salomão cantavam seus salmos; quando Isaias anunciava ao seu povo a vinda futura do Filho do Homem; quando Ezequiel contemplava o Senhor dos dias sentado no trono da sua glória, mais de mil anos já pesavam sobre muitas dessas árvores. O Grizzly Gigante contava com dois mil anos quando no Gólgota foi erguida aquela árvore da qual cantamos: "Verdadeira árvore na qual pendeu o Senhor, mergulhado em angustia mortal". O canto de luto do paraíso, o canto da árvore da vida dos deuses germânicos, o canto de vitória da árvore da redenção. Toda a simbólica nas sagas e na arte da humanidade toma conta do caminhante na penumbra mortiça dessa floresta. Há muitas verdades entre o céu e a terra que não se encontram nos livros. Revelam-se no silêncio da floresta. ${ }^{26}$

Depois do parque das sequóias, constava na programação de viagem uma visita ao Parque Nacional do Grand Canyon. Ao ler o diário em que narra essa viagem nos mínimos detalhes, desdobra-se na imaginação um mapa tão perfeito, tão detalhado e tão real, que simula estarse participando fisicamente da vivência. A estrada cruza o território no qual foi vivida e construída a saga da conquista do oeste pelos cowboys. Como era de seu costume, antes de cada etapa de viagem lia obras sobre as características físicas e as histórias de que o percurso tinha sido palco no passado e o que estava acontecendo no presente. Alimentava uma secreta simpatia por aqueles personagens rudes que consolidaram a conquista do oeste americano. Ele deve ter visto, nesses pioneiros, réplicas dos guerreiros gregos que povoam os cantos da Ilíada e Odisséia de Homero, que carregava sempre consigo e não deixava de ler diariamente pelo menos alguns versos, no original grego. Resumiu a personalidade do cowboy como sendo o rancheiro modelo de virtudes e de um homem que se contrapõe ao vilão encarnando todas más qualidades que um homem pode oferecer. $\mathrm{O}$ conflito entre os dois é inevitável porque o mau rancheiro é ladrão de gado, bandido mascarado e assassino em série, enquanto o bom

${ }^{26}$ RAMBO, B., 1956. Op. cit., p. 154-155. 
rancheiro é defensor da lei, protetor dos fracos, um homem que às vezes reza. Ambos atiram igualmente bem, com uma mão, com as duas, para frente, para trás, simultaneamente para a direita e a esquerda. A ambos acompanha um bando de cowboys que cavalgam tão bem quanto atiram, leais no mal, leais no bem, grandes no beber, grandes no dançar e grandes na bandalheira, contudo cavalheiros até a morte pela mulher honrada. Mas é contemplando a grandiosidade do Grand Canyon, que desenha mais um desses mapas que são marca registrada sua, no qual a natureza inanimada é povoada por animais, pássaros e uma galeria de personagens históricos procedentes dos mais diversos continentes e culturas, e sugerem uma amostra do "melting pot", o cenário de síntese histórica e cultural que é a América:

A margem oposta eleva-se a 1.700 metros. A altitude maior chega a 2.500 metros, quase encostando na região das altas montanhas. Um anfiteatro único no mundo descortina-se diante dos olhos. Sobre o leito do rio eleva-se gradativamente o Tonto Plateau, coberto pelo sagebush (arbusto de lugares semidesérticos), até ser substituído pelos terraços, torres e castelos de rochas, mais acima. Os degraus, envoltos nas cores amarelo, marrom e ferrugem, recuam cada vez mais. Sobrepõem-se na medida em que sobem até terminar em dorsos isolados, não poucas vezes distantes uns dos outros, em montanhas com formato de mesa e pontas rombudas nos mais diversos formatos. Os americanos buscaram para essas montanhas singulares nomes no mundo dos deuses e das lendas. Ergue-se aí o templo de Shiva, o Buda e Brahma da mitologia indú, o Templo de Confúcio da antiguidade chinesa, o Templo de Zaratustra da antiga mitologia persa, o Walhala das lendas dos deuses germânicos, o Trono de Siegfried da canção épica alemã. Mais abaixo, ergue-se a Pirâmide de Quéops da antiga história do Egito. Mais adiante desse conjunto de torres, pirâmides, tronos, templos e milhares de castelos de rochas desmoronando, na margem norte, 30 quilômetros distante, duas faixas de rochas bancas fecha a paisagem. Nuvens de tempo bom velejam por sobre o vale. Um falcão precipita-se perpendicularmente no abismo. Um Chipunk (esquilo terrestre) célere como um raio e uma ave semelhante às nossas gralhas nos pinhais disputavam um petisco na frente dos meus pés. ${ }^{27}$

Depois dessa descrição da fisionomia geográfica do Grand Canyon e as simbologias históricas que os americanos souberam encarnar nos seus grandiosos acidentes, o Padre Rambo mostra toda a sua maestria literária ao descrever o amanhecer e o entardecer naquele cenário:

Nos dias seguintes passei muitas horas sentado aqui no alto, contemplando o Grand Canyon no jogo da alternância da luz e das cores. Quando os primeiros raios do sol da manhã, vindos da direção do Painted Desert, derramam a sua luz sobre os abismos escuros, os rochedos do leste brilham na tonalidade ouro de uma delicadeza impossível de definir, enquanto nas encostas do oeste os vales e abismos jazem mergulhados em cores negro azulado. Pela hora do meio dia as cores fortes vão desmaiando para o amarelo cinza, o marrom cinza, o vermelho ferrugem e o branco. No final da tarde, repete-se, na seqüência inversa, a mudança dos jogos de luz e de sombra da manhã. Mas o vermelho dourado do sol da manhã cede lugar ao vermelho púrpura do ocaso. A maioria das fotos coloridas que são reproduzidas em livros, foram tiradas naquele horário e deixam a impressão de que o Grand Canyon veste por natureza esse manto colorido. Pouco depois do por do sol, o vermelho passa para o púrpura-escuro e as tonalidades cinza, amarelo e verde, modificam-se para um azul fantasmagórico, que vai mergulhando cada vez mais na escuridão da noite. ${ }^{28}$

Seria um grande engano pensar que o Padre Rambo dava vazão à compreensão do mundo e

\footnotetext{
${ }^{27}$ RAMBO, B., 1956. Op. cit., p. 180-181.

${ }^{28}$ RAMBO, B., 1956. Op. cit., p. 181.
} 
da natureza e à relação existencial que cultivava com ela, quando em contato com cenários que nunca tinha visto de perto. O cenário com o qual consolidou, desde o final da década de 1930 até o seu falecimento, uma relação existencial tão profunda que o chamou de "minha pátria na terra", foi o planalto sul-rio-grandense, com seus campos, capões matas, pinheirais, cânions, escarpas e precipícios. Cambará e arredores formam o ponto de referência e convergência desse cenário. As anotações e reflexões que deixou foram extraídas do diário que escreveu durante a estadia durante os meses de janeiro e fevereiro de 1948, naquela região:

Essas caminhadas pela neblina, essas noites com seu leve prurido de chuva junto à janela, as gotas continuamente estalando nas árvores, chamam a interioridade. Então a alma liberta-se dos fogos fátuos do dia resplandecente, e ela entra em silêncio no seu mundo mais íntimo, no reino do ser envolvido no sonho de todas as coisas. Luzes distantes e vozes se perdem em seu eco e migram através desta terra espiritual carregada de pressentimentos. Alguém caminha na névoa da noite com passos tão leves como o murmúrio da neblina. Ele é único e chama meu nome nesta terra solitária. Ó tu, noite silente e santa de solidão!

A orla oriental é constituída pela vista panorâmica para as maiores distancias, pela sinuosidade brusca das formas perto da planície e com a força perene da névoa em efervescência.

São únicas as pinturas da natureza, como as da garganta da Pedra Branca, na bela terra de Deus. Poderia se chamar o quadro de precipícios perpendiculares e de cataratas troantes, de névoas efervescentes e trovoadas uivantes, de mata silente e escolhos altos, cheios de clarividências pétreas, pintura imperfeita, mas bem mais do que isso. É uma construção gigantesca de força e simplicidade que nunca para de rolar para frente. Alguém mora nessas profundezas que sussurram, alguém observa nesta torre solitária de vigia. Ele chama o eco, apascenta a névoa, brinca com o raio e o trovão nos lugares solitários.
$\mathrm{Na}$ ampla baixada, os lagos refulgentes e o mar-oceano aos sussurros ficam depois desta paisagem. Ao olhar ao longe da parede anterior, há pressentimento das distancias infinitas. O sentir predominante é o da preeminência sobre o vapor, a poeira, o calor e a fastidiosa multidão humana. Rochas cinzentas, mata verde, água murmurante e correntes estagnadas, amplas planícies, nuvens migrantes e, finalmente, o mar insondável: também isso é solidão da alma com Deus! O Espírito de Deus sopra em toda a parte. Quem ergue o chão de sua alma na solidão de Deus há de levar esse sentimento mesmo em meio à multidão insana!

Nunca esquecerei minha despedida da orla oriental. Meu cavalo avançou à vontade pelo campo florido. Atrás de mim as névoas condensadas, vindas do precipício rolavam pelo campo. É o atrito da planura inferior que faz surgir esse verdadeiro rolar e rodar. Essa neblina fria rodou sobre mim e me envolveu. Murmuravam os arroios e cochichavam os pinheiros. Era a saudade de épocas geológicas distantes, dos irmãos do Chile e dos parentes de muito além do Oceano Atlântico, nas ilhas solitárias do Mar do Sul.

Agradeço a Deus e levo saudades desta terra hospitaleira. Se possuo uma pátria no mundo, ela está no planalto calmo e sereno, à sombra dos pinheirais. ${ }^{29}$

\section{CONSIDERAÇÕES FINAIS}

Fui buscar no diário que escreveu durante a visita que fez aos grandes parques do oeste dos Estados Unidos da América, assim como no diário de Cambará, o perfil do Padre Rambo naquilo em que ele se destaca em relação, por exemplo, a Erich Wassmann, Teilhard de Chardin, Ludwig von Bertalanffy, ou Edward Wilson e Francis Collins. Balduíno Rambo não se contenta, como seria hábito de um botânico - e mais ainda de um sistemata -, com as observações e os registros técnicos, frios e objetivos da flora local. O que o motiva no fundo, no fundo, é a descoberta de como as plantas, os ani-

${ }^{29}$ RAMBO, B. Diário (inédito), 9 de fevereiro de 1948. 
mais, os homens, a história geológica, os acidentes geográficos, a história humana, as cores, os sons, as formas e os simbolismos que sugerem, compõem um cenário harmônico. No seu entender subjaz ao panorama visível e o perpassa e vivifica uma causa invisível, mas perceptível para aquele que possui a mente e os sentidos da alma suficientemente atentos. Para ele, o silêncio da floresta é mais eloqüente do que tudo que os livros já registraram. Parte do pressuposto de que o universo, o mundo, a natureza e tudo que contém e oferece, principalmente o homem, inserem-se num plano Criador e como tal obedece a uma teleologia. O que Teilhard de Chardin chamou de "alfa", o Padre Rambo não hesita em chamar de ato criador divino no começo das coisas e o "ômega" como o ponto de chegada final, depois de cumpridas todas as etapas previstas pelo Criador no plano da evolução. Como tal também a natureza representa o mais autêntico livro da Revelação. A revelação apresentada no Antigo e Novo Testamento é parcial e, como tal, incompleta, truncada e distorcida pelos cacoetes históricoculturais consolidados na tradição judaico-cristã. O livro aberto da Revelação por excelência é a natureza. Finalizo com a sua conclusão: "Desemboca isso mais uma vez nos pensamentos básicos de minha Weltanschauung (cosmovisão), a saber: que a simples existência objetiva de todas as coisas já importa na maior Revelação e Glorificação de Deus. Nisso incluso também se acha o sentido misterioso da palavra do Senhor: Contemplai os lírios do campo! ... Vede os pássaros do céu ... ${ }^{30}$

\section{REFERÊNCIAS BIBLIOGRÁFICAS}

BERTALANFFY, L. von. Teoria Geral dos Sistemas. Petrópolis: Editora Vozes, 2008. 360 p.

CHARDIN, T. de. O lugar do homem na natureza. Lisboa: Instituto Piaget, 1956. 155 p.

CHARDIN, T. de. O fenômeno humano. São Paulo: Ed. Cultrix, 1986. 392 p. 1986.

COLLINS, F. A linguagem de Deus - Um cientista apresenta evidências de que Ele existe. São Paulo: Editora Gente, 2007.

DALTO, R. Aparados da Serra: na trilha do Pe. Rambo. São Leopoldo: Ed. Unisinos, 2007. 143 p.

RABUSKE, A. Balduino Rambo: cientista e religioso. In: RAMBO, A.B.; GRÜTZMANN, I.; ARENDT, I.C. Pe. Balduino Rambo - A pluralidade na unidade: memória, religião, cultura e ciência. São Leopoldo: Editora Unisinos, 2007. p. 35-65.

RAMBO, A.B. Novas respostas para velhas perguntas. In: RAMBO, A.B.; GRÜTZMANN, I.; ARENDT, I.C. Pe. Balduino Rambo. A pluralidade na unidade. São Leopoldo: Ed. Unisinos, 2007. p. 11-33.

RAMBO, B. A fisionomia do Rio Grande do Sul. Ensaio de monografia natural. Porto Alegre: Of. Gráf. da Imprensa Oficial, 1942. 360 p.

RAMBO, B. Diário (inédito), 9 de fevereiro de 1947

RAMBO, B. Diário do retiro (inédito), 31 de julho a $1^{\circ}$ de agosto de 1949.

RAMBO, B. Diário (inédito), 3 de junho de 1951.

RAMBO, B. Três meses na América. Manuscrito (inédito), 1956.

RAMBO, B. A nacionalização. Arquivo do Padre Rambo (inédito), 1958. p. 222.

RAMBO, B. Em busca da Grande Síntese. São Leopoldo: Editora Unisinos, 1994. v. 1. 404 p.

WASSMANN, E. Stimmen der Zeit, 1921, v. 100.

WILSON, E. A criação - um apelo para salvar a vida na terra. São Paulo, Companhia das Letras, 2008.

${ }^{30}$ RAMBO, B. Diário (inédito), 9 de fevereiro de 1947. 